\title{
A Brief Anatomy of Adjudicative Rule-Formalism
}

\author{
Frank I. Michelman $\dagger$
}

\section{RULE-FORMALISM}

In law, there are sundry formalisms. It is "formalist" (never a term of endearment, to my ear) to affirm the equal rights of the rich and the poor to eat cake or to sleep under the bridges of Paris. It is also "formalist" to think that legal-normative terms like "contract," "liberty," "fault," and "cause" are names of intelligible essences or to pretend that the decisive legal norms for any pending case are uniquely deducible from other norms in a logically unified normative system. None of those dubious doctrines has been front-and-center in this Symposium. What draws the Symposium together is a plainer-minded prompting. It is, I would say, a pragmatic expectation of important social benefits from a general disposition of lawmakers and adjudicators to construct into legal norms the grammatical property of "ruleness" or formal realizability. To distinguish this plain-minded, pragmatic formalism from the other, more extravagant kinds I mentioned at the start, let us call it "rule-formalism." The anticipated benefits of rule-formalism sound in democracy, efficiency, accuracy, equality, and liberty. Compared with a law composed of vague standards or of multiple, competing principles, a "law of rules," as Justice Scalia has called it, ${ }^{1}$ is said to score high on measures of transparency to democratic evaluation and revision, conduciveness to both economic efficiency and moral aptness, consistency in the application of legal coercion to various persons at different times and places, and release from uncertainty about the law's bearing on plans and projects.

I take rule-formalism to be a prescriptive doctrine, meant to advise certain classes of public officials about how they ought to manage their public powers and responsibilities. Among the intended advisees, no doubt, are drafters of statutes and regulations; as to them, the intended advice-legislative ruleformalism, as we might call it-is as clear and simple as can be:

† Robert Walmsley University Professor, Harvard University.

1 Antonin Scalia, The Rule of Law as a Law of Rules, 56 U Chi L Rev 1175 (1989). 
Make rules not standards, unless, perhaps, you have a really pressing reason to do otherwise.

What about judges? What is the intended rule-formalist advice to them? What, in other words, is adjudicative ruleformalism? The answer is not as simple as you might think, and in fact a bit of intellectual labor is required to unpack it fully. Noticing that none of the main papers really does this work, I offer it as my skeptical bystander's contribution to the Symposium. Perhaps the result will show adjudicative rule-formalism to be a more interesting, a more venturesome, and a more problematic doctrine than you might at first have thought.

\section{Posttive AND IMmanent LegaL NoRMS}

A legal norm, let us say, is a judicially recognized constraint on adjudicative decisionmaking. Legal norms can be either "positive" or "immanent." Positive legal norms are the constraints on adjudication that judges treat as relevant to their task because they see them as having been laid down intentionally by the acts of certain agents whom the judges recognize as authorized to lay down constraints on adjudication. Among such agents might be duly constituted lawmaking bodies, but also among them might be the parties to contracts or the makers of deeds, trusts, and wills. Immanent legal norms are other constraints on adjudication, if there are any, that adjudicators recognize as relevant to adjudicative work. Immanent legal norms may or may not exist for any given judge in any given case. If there are factors and considerations that judges treat as compelling upon their adjudications, but whose relevance for them they do not trace to the intentionally norm-declaring acts of specific agents, then those factors and considerations are immanent legal norms. For example, a judge might feel called upon to interpret legal materials, insofar as possible, to avoid sharply retrospective effects-not because there is positive law against retrospectivity but because (so the judge believes) avoidance of retrospectivity is implicit in the very idea of legal ordering.

How does that classification apply to the adjudicative constraints that judges read out of (or read into) judicial precedents? For our purposes here, those constraints will have to be classified as positive legal norms. We shall have to picture each individual judge as recognizing the collective judiciary-not only the common law judiciary but also the judiciary collectively engaged in statutory interpretation - as a duly authorized, external, antecedently acting lawmaking body laying down the law to him or her. We can and must extend this picture even to the case in which 
the highest court of a jurisdiction purports to make what it regards as a new rule for application to the matter right now before it. In that case, we must say that the court has acted both as a duly constituted lawmaking body and as an obedient adjudicator, in that order, and that its new rule-the new precedent-has become a positive legal norm for future cases.

I don't offer these classificatory stipulations as either a true account of how judges understand what they do or as the essence of the best speculative jurisprudence. Rather I am forced into them by my aim of providing a fully unfolded account of the prescriptive notion of adjudicative rule-formalism. For it is apparent, when you think about it, that the admonitions of adjudicative rule-formalism can apply only to those judges who are acting consciously in the presence of at least one, concededly relevant, positive legal norm. It is perhaps not impossible to imagine the opposite setting, of a tribunal set up for the purpose of handing down unique resolutions of disputes brought before it, in a society that obdurately refuses any semblance of general, anticipatory lawmaking - even by a tribunal binding itself as it goes along by making precedents. In such a decidedly antilegislative setting, if it is imaginable, the prescriptive admonitions of adjudicative rule-formalism would be not only pointless but unthinkable. Yet those admonitions plainly are intended to cover both common law adjudications and those statutory adjudications (most antitrust and civil-rights cases, for example) in which prior judicial interpretations of the governing statutes have supplanted the statutes as the immediate source of governing norms for adjudication. It is, therefore, necessary for us to define the category of positive (as opposed to immanent) legal norms in such a way as to cover cases of these kinds.

\section{The ADJUDicative RULE-Formalist DOUBLE BIND: MAKE NO STANDARDS, SEE NO STANDARDS}

Adjudicative rule-formalism comprises not one but two distinct directives to judges adjudicating in the recognized presence of positive legal norms. The first and more obvious is the exact counterpart of the "make rules not standards" directive of legislative rule-formalism. Call it the "make rules" directive. It calls upon judges, insofar as possible, to construe all express, positive legal-normative materials into statements both plain in meaning and rule-like in structure, so that, in sum, applications of them can thenceforth be mechanical and uncontroversial. Justice Scalia has spoken clearly and strongly for this "make rules" aspect of adjudicative rule-formalism. He wants his Court to con- 
struct all the normative expressions in the Constitution and law books into rules, and not leave any of them languishing in the form of standards, even though when judges construct rules out of standard-like constitutional or statutory language, they undoubtedly and very visibly engage in lawmaking. ${ }^{2}$

\section{A. Exclusion of Legislative Purpose}

Let us now turn to the second directive of adjudicative ruleformalism, which we can call the "only rules" directive. Consider Larry Alexander's contribution to this Symposium. ${ }^{3}$ Judges, Alexander maintains, ought rigorously to treat the law as consisting only of express, positive legal norms or, in other words, to treat the aggregation of relevant, express, positive legal norms as all the relevant law there is. He thus frames legislative purpose out of proper judicial cognizance. A society presumably has reasons for entrusting legislation to selected persons or bodies. A judge might think that it is, therefore, incumbent on the judiciary to seek the controlling norms for judicial decision in the intentions or reasons that moved the selected persons to utter certain sentences as law, not just in the sentences themselves. On that view, fidelity to lawmakers and society requires judges in all cases to make fresh assessments of how the lawmaker's intentions or reasons do or do not apply to the case in question. Not, however, according to the "only rules" directive of adjudicative rule-formalism. That directive, to the contrary, requires judges to suppress thoughts of that kind and limit themselves to applying the uttered sentences straightforwardly, according to what the sentences say, not according to why (the judges think) their authors said it or what (the judges think) their authors intended to accomplish by saying it.

\section{B. The Question of Residual Positive Legal Norms}

But it seems that the "only rules" directive of adjudicative rule-formalism cannot, in all reason, stop there. Additionally, it must require exclusion from the adjudicative purview of everything that is not either a fact of the case or an express, positive legal norm (shaped up, insofar as the judges can do so, into the form of a rule). That means it must exclude immanent (nonpositive) legal norms, if there are any, and also residual (as opposed to express) positive legal norms, if there are any of those. A "re-

\footnotetext{
2 See id at 1179-80.

s See Larry Alexander, "With Me, It's All er Nuthin": Formalism in Law and Morality, 66 U Chi L Rev 530 (1999).
} 
sidual" (as opposed to an "express") positive legal norm is one whose content is thought to be gatherable quite apart from anything ever said about it by duly authorized lawmaking bodies. Such a norm may nevertheless figure as a positive (as opposed to an immanent) legal norm insofar as its status as law is thought to depend on the lawmakers having said something about it, at least implicitly-namely, that it is law.

Such nonexpress or "residual" positive legal norms might include "general softeners" such as equity, lenity, desuetude, and general canons of construction. They might also include more value-specific considerations drawn from background normative sources such as custom, course of dealing, universalist morality, or specific political-moral traditions such as natural law, natural right, or the common law tradition. I suspect that most lawyers, if they thought about it, would find themselves quite certain that residual positive legal norms do most definitely and significantly exist in our legal system. But whether they exist or not, it seems that the "only rules" directive of adjudicative rule-formalism must frame them out of adjudicative consideration. In effect, the "only rules" directive ties back into the "make rules" directive by requiring judges to construe express positive-legal sources (instruments and sentences) so that they do not implicitly incorporate any residual norms. They ought not, for example, incorporate residual positive legal norms in the way that many lawyers maintain our Constitution's Due Process Clauses incorporate a specific tradition of "natural right" or common law liberty. Why must this be a requirement of adjudicative rule-formalism? Because residual legal norms, being by definition nontextualized or "unenumerated," are more or less bound to be cognizable, if cognizable at all, only as standards or principles, not rules. ${ }^{4}$

Imagine a country's supreme court going about its business of constitutional adjudication in the following way. First, it assiduously translates all the normative sentences and sentencelike expressions in the constitution to mechanically applicable rules without remainder. For example, it reads a search and seizure clause, identical with that in our Constitution's Fourth Amendment, ${ }^{5}$ either to prohibit warrantless searches in all cir-

- Consider, for example, the jurisprudence-of-principles style of the Supreme Court's adjudications in cases such as Griswold $v$ Connecticut, 387 US 479 (1965), Moore v East Cleveland, 431 US 494 (1977), and Planned Parenthood of Southeastem Pennsylvania $v$ Casey, 505 US 833 (1992) (plurality opinion). At the end of these reflections, I shall briefly reconsider the claim that adjudicative rule-formalism must be committed to excluding all "unenumerated" considerations from the attentions of judges.

s uThe right of the people to be secure in their houses, persons, papers, and effects 
cumstances or, oppositely, to mean that a warrant is not prerequisite to the legality of a search in any circumstance. Second, the court maintains that the country's constitution, regarded as a positive legal instrument, has injected into the country's constitutional law some "unwritten" norms from a general world tradition of democratic constitutionalism. These additional, residual norms include a test of "proportionality," meaning that prima facie infractions of the constitution's prohibitory rules are not illegal unless they are "not reasonably justifiable in an open and democratic society based on human dignity, equality, and freedom." They also include a test of "civility," meaning that governmental acts are illegal, although contravening no express provision of the constitution, if they deviate from "the evolving standards of decency of a maturing society." No matter which of the two opposite, maximally rule-like readings of the search and seizure clause our imaginary court adopts, the net result will be that some warrantless searches are legal, some are illegal, and legality will have to depend, at least for a while, upon the application of a highly standard-like legal test.

Over time, of course, a set of rule-like guidelines may develop for applying the standard-like tests to certain, recurrent fact patterns. It may, or it may not, depending on the disposition of the court. Thus in the final analysis the court in my story may or may not end up having comported itself in the way that ruleformalists believe will reap for society the benefits of democratic accountability, economic efficiency, moral accuracy, calculability, and fair consistency of applications of legal force. From the standpoint of adjudicative rule-formalism, the danger is that the court, although rigorously following the "make rules" directive for the treatment of express positive legal material, will nevertheless have failed to follow the other critical directive, the "only rules" directive, of adjudicative rule-formalism.

From this example, we can see the following. First, the two directives of adjudicative rule-formalism are distinct both conceptually and practically. One easily can imagine a judiciary adhering to either one without adhering to the other. Second, from a rule-formalist standpoint, there seems little point in having either directive in force without the other.

against unreasonable searches and seizures shall not be violated, and no Warrants shall issue, but upon probable cause." US Const, Amend IV.

- Compare Constitution of the Republic of South Africa, 1996, \&36.

7 Compare Trop v Dulles, 356 US 86, 101 (1958). 


\section{THE CHALlENGE FOR ADJUDICATIVE RULE-FoRMALISM}

We are now in a position to pose some questions that might be worthy of the attention of adjudicative rule-formalists. First, would the exclusion from the adjudicative purview of all immanent or residual positive legal norms be a morally acceptable practice to commend, across the length and breadth of the law, to public officers exercising the always coercive and often punitive force of law? Second, could the main body of society, or even of the judiciary, possibly be brought around to agreeing that it would be? Is the framing-out of all immanent and residual positive legal norms a feasible aim in any legal-cultural setting now found on earth? What are the chances that any effort to accomplish that aim would probably fail by some substantial margin? Third, if such an across-the-board framing-out either ought not or cannot be completely or nearly completely accomplished, does enough remain of the adjudicative rule-formalist project to make it worth trying to carry out? Is the project one that would better be confined to specific areas of law? What are the applicable second-best principles?

I don't have the answers, I'm just asking.

\section{ADJUDICATIVE RULE-FORMALISM AND DEMOCRATIC LEGITIMACY}

In his presentation at the conference for which the essays in this Symposium were first prepared, Cass Sunstein doubted whether disputes over adjudicative rule-formalism can sensibly be resolved by appealing to the idea of political legitimacy. I want to end these reflections with some support of my own for Professor Sunstein's doubt.

My support flows from a certain rough conception of what it is for a judicial decision to be legitimate, a conception that I simply posit. I do not try to defend it here. According to the view I have in mind, a judicial decision is legitimate if and only if the parties and others see it as a competent and sincere attempt to decide according to values, and only according to values, that have approval or acceptance from institutions that are accountable, on a fair basis, to everyone in the country. We can call this "democratic legitimacy." Advocates of adjudicative rule-formalism sometimes claim that democratic legitimacy supports their stance. ${ }^{8}$ It is only, they suggest, if the judiciary sticks to enforcing express positive legal norms, cast insofar as possible in rule-like

\footnotetext{
- See Scalia, 56 U Chi I Rev at 1176 (cited in note 1).
} 
form, that the parties and others can possibly perceive their decisions as having been driven by democratically approved values and nothing else.

I do not see how this particular justification of adjudicative rule-formalism can possibly succeed. Democratic legitimacy, remember, presupposes that we have assurance that the country's positive lawmaking institutions are in fact accountable, on a fair basis, to everyone in the country. But the view is widely held that the fair accountability of lawmaking institutions to everyone implies that certain kinds of individual rights, and maybe needs, are universally respected and fulfilled, and that the country's basic political and economic structure-its basic patterns of distribution of power and status-conform to certain limits on inequality, stratification, and subordination. ${ }^{9}$ Of course, those rights, needs, and limits, whatever they are, are what they are regardless of any democratic pedigree. They must be, because they are a part of our conception of what democracy is.

If so, then the presumed fulfillment of these needs, rights, and limits is preconditional to any possible conclusion that adjudicative rule-formalism caters to democratic legitimacy. And it is hard to see how their preconditional status can be reconciled with any doctrine that would restrict judicial attention to norms and values that visibly have received the approval of currently entrenched political institutions. Such a doctrine would blind the law to the possibility that these institutions, or their manner of operation, currently fail to give their dues to rights, needs, and limits that really are preconditional to accountability, on a fair basis, to everyone in the country. Which means, if our earlier "anatomy" of adjudicative rule-formalism was on the mark, that democratic legitimacy and adjudicative rule-formalism are adversaries no less than allies; or, in a banal rendition of the state of affairs, that the relationship between the two is, as they say, conflicted. Imagine someone is shouting at your judiciary the following two instructions: (1) Focus only on expressly enacted legal norms. Do not ever soften, leaven, or mix them with any considerations not themselves drawn from express enactments. ${ }^{10}(2)$ Act only in response to values for which you can find and show positive approval by political institutions that really are accountable, on a fair basis, to everyone in the country. The instructions appear to contradict each other.

- See, for example, Ronald Dworkin, Freedom's Law ch 1 (Harvard 1996); John Hart Ely, Democracy and Distrust (Harvard 1980); John Rawls, Political Liberalism 324-31 (Columbia 1993).

${ }^{10} \mathrm{I}$ am writing this just a few hours before the first night of Passover. 
Does this contradiction suffice to rule out the possibility of democratically legitimate adjudicative rule-formalism? It does not. Why? Because the possibility remains that an adjudicative method might be rule-formalist even if it admitted into the adjudicative purview some considerations not specified by express positive legal enactments. More specifically, the possibility remains that one can deduce from the very notion of "accountableon-a-fair-basis-to-everyone" a complete set of all the rules and sub-rules that judges would need to resolve all of the controversies bearing on this matter that might ever come before them.

If you believe that is so, then you are a "formalist" in the second of the extravagant senses I listed at the outset of these remarks, ${ }^{11}$ the kind of formalist that Larry Alexander bemusedly calls a "conceptualist."12 But I gather, in part from Alexander's essay, that sober and sensible rule-formalists shun conceptualism. Those who do, I am suggesting, cannot easily appeal to democratic legitimacy as a reason to support across-the-board adjudicative rule-formalism.

That is not, I freely grant, a conclusive reason to withhold support from across-the-board adjudicative rule-formalism. The sacrifice of democratic legitimacy might, after all, be a price you are willing to pay for the anticipated pragmatic benefits.

"Formalist" in the sense of believing that legal-normative terms like "contract," "liberty," "fault," and "cause" are names of intelligible essences or pretending that the decisive legal norms for any pending case are uniquely deducible from other norms in a logically unified normative system.

${ }^{12}$ Alexander, $66 \mathrm{U}$ Chi L Rev at 531 n 2 (cited in note 3). 